\title{
Mapping Value Perspectives on Wind Power Projects: The Case of the Danish Test Centre for Large Wind Turbines
}

\author{
Borch, Kristian
}

Published in:

Energy Policy

Link to article, DOI:

10.1016/j.enpol.2018.08.056

Publication date:

2018

Document Version

Peer reviewed version

Link back to DTU Orbit

Citation (APA):

Borch, K. (2018). Mapping Value Perspectives on Wind Power Projects: The Case of the Danish Test Centre for Large Wind Turbines. Energy Policy, 123, 251-258. https://doi.org/10.1016/j.enpol.2018.08.056

\section{General rights}

Copyright and moral rights for the publications made accessible in the public portal are retained by the authors and/or other copyright owners and it is a condition of accessing publications that users recognise and abide by the legal requirements associated with these rights.

- Users may download and print one copy of any publication from the public portal for the purpose of private study or research.

- You may not further distribute the material or use it for any profit-making activity or commercial gain

- You may freely distribute the URL identifying the publication in the public portal

If you believe that this document breaches copyright please contact us providing details, and we will remove access to the work immediately and investigate your claim. 
Title: Mapping Value Perspectives on Wind Power Projects: The Case of the Danish Test Centre for Large Wind Turbines

Dr. Kristian Borch, PhD

Technical University of Denmark

Keywords: wind power; energy planning; spatial planning; value framework; social acceptance; community acceptance.

Abstract: Social acceptance of wind power is a complex matter, and national public interest does not necessarily translate into local public interest. If community concerns is disregarded in public spatial planning and the private development of wind power projects, the expected increase in the production of wind power energy will be jeopardized. Value propositions for installing wind farms in a community often consider only national policy targets, end users and those organizations that make a profit on installing, running or owning a wind turbine power plant. In many cases, the impact of technologies on society is underestimated, especially the impact on those actors who are influenced by technological change but without perceived benefit. This paper applies a value framework to systematically analyse the perceived value of the National Test Centre for Large Wind Turbines in Denmark, considering different stakeholder dimensions of acceptance (socio-political, market and community) from four perspectives (economic, psychological, sociological and environmental) before arriving at some policy recommendations on how to incorporate community values when planning for wind power.

\section{Abstract}


Social acceptance of wind power is a complex matter, and national public interest does not necessarily translate into local public interest. If community concerns is disregarded in public spatial planning and the private development of wind power projects, the expected increase in the production of wind power energy will be jeopardized. Value propositions for installing wind farms in a community often consider only national policy targets, end users and those organizations that make a profit on installing, running or owning a wind turbine power plant. In many cases, the impact of technologies on society is underestimated, especially the impact on those actors who are influenced by technological change but without perceived benefit. This paper applies a value framework to systematically analyse the perceived value of the National Test Centre for Large Wind Turbines in Denmark, considering different stakeholder dimensions of acceptance (socio-political, market and community) from four perspectives (economic, psychological, sociological and environmental) before arriving at some policy recommendations on how to incorporate community values when siting wind turbines.

Keywords: wind power; energy planning; value framework; social acceptance; community acceptance; wind turbine siting

\section{Introduction}

Wind power systems are expected to contribute significantly to Danish fossil-free energy production by 2050, and community acceptance is an important element for meeting this ambitious target. However, in Denmark and many other countries, the degree to which wind energy is seen as a public good changes when citizens are confronted with an application for developing wind turbines in their vicinity (Wolsink, 2007). This change in attitude has often been characterised as self-interested and irrational (often under the stigmatising umbrella term Not-InMy-Back-Yard or NIMBY) (e.g., Devine-Wright, 2011; Van der Horst, 2007; Wolsink, 2007). 
This approach to technological change in local communities gives rise to miscommunication, lack of trust and unnecessary escalations of controversies. Hence, it is a well-established fact that sitings of large technical facilities often create controversy, and wind turbines and their associated technological artefacts are no exception (Batel et al., 2015).

Although Denmark has been very successful in developing onshore wind power since the eighties and public acceptance of wind power has been considered high (Sørensen et al., 2002), Denmark has witnessed a growing concern in local communities neighbouring planned sitings of wind turbines. The concerns have been expressed as various arguments against specific sitings in local media and legal hearings, which have delayed or stalled planned wind power projects in several municipalities across Denmark (Anker, 2016).

Public acceptance is a complex matter, and national public interest in wind power does not necessarily translate to a local context (Bergek, 2010). Therefore, it is not surprising that municipality planners find it difficult to accommodate contextualized citizen concerns (Huber et al., 2012). These concerns often lead to protests and empirical evidence has convincingly argued that referring to protests as NIMBYism is opaque, inappropriate, and unhelpful (e.g., DevineWright, 2011; Van der Horst, 2007; Wolsink, 2007). It has been postulated that conflicts on wind turbines are limited to land-based developments, and off-shore wind parks are less problematic alternatives. However, wind farms off the coast of the UK have not proceeded without opposition or conflicts (e.g., Devine-Wright and Howes, 2010; Ellis et al., 2007; Eltham et al. 2008). Thus, studies of wind farms outside Massachusetts and Delaware, US, show that the majority of the public expects negative impacts from the project (Firestone and Kempton, 2007; Lilley et al., 2010). Different attributes have been reported to influence the attitudes towards and acceptance of off-shore wind farms in Denmark (Ladenburg and Möller, 2011). In any case, land-based wind power has a significantly lower LCOE (levelized cost of energy) compared to offshore wind power. 
Value propositions for installing wind farms in a local community often consider only national policy targets, and the economic value often benefits remote investors rather than the local community. Therefore, negative value from socio-technical conflicts is underestimated, especially from a community acceptance perspective (Wüstenhagen et al., 2007). Such ambiguity regarding the value proposition may lead to anxiety and lack of recognition of wind power projects among citizens in local communities. As den Ouden (2012) (p.19) puts it, 'A more integral view on value is needed that will help organizations to create innovations that bring value to users and society. Such an integral view should include potential harmful effects and support creative processes to reduce harm and increase value.' Thus, combining the acceptance perspectives from Wüstenhagen et al. (2007) with den Ouden's Value Framework is help full to analyse value proposition to increase the perceived value of wind turbines in the community.

However, the notion of 'value' is ambiguous. Thus, technological change itself should not only be of value to the immediate stakeholders but should also contribute to the interests and values of the community in which the change is embedded. Thus, 'value' refers to the value of something, whereas 'values' refer to a more holistic and comprehensive view of what is important in life. These different views on values lead to different, polarised narratives on technological change, which often lead to controversies and conflicts over wind turbine sitings in communities.

Today, wind power planning is dominated by the industrial paradigm focusing on shareholder value and profit maximization. Policy measures to mitigate conflicts between local communities and wind power developers can be found in the Danish legal framework; however, these measures only address economic interests in the form of compensation for loss of property value due to nearness to wind turbines and a community benefit scheme (providing funding for local projects that enhance the landscape or recreational values or promote cultural and informative activities) (Anker and J ørgensen, 2015). Furthermore, a co-ownership scheme obliges developers to offer a minimum of 20 percent ownership shares to local residents (Ibid.). Recent studies on wind power 
controversy in Denmark (CONCITO, 2018) have demonstrated that these compensation measures are often perceived inappropriate and the citizens do not consider the community benefit scheme of value to them, but rather a contribution to the municipality budget (J ørgensen, 2018). In addition, proponents of wind power projects consider it immoral to invest in co-ownership and see it as a provocation that conflicts with their interests and basic values (J ohansen and Emborg, 2018).

The aim of this paper is to use discourse analysis to map themes of controversy over 'values' followed up by discussion of what 'value' entails from different stakeholder dimensions and perspectives using the Value Framework (den Ouden, 2012). The hypothesis is that the combination of controversy mapping and Value Framework can give a more varied picture of perceived stakeholder 'values' concerning technological change and in turn help authorities and developers ameliorate conflicts over loss of local values in the wind turbine planning process. The legitimacy in this hypothesis comes from community studies that show that local patriots are not necessarily against wind power; instead, their focus is on legitimate, community-relevant concerns (Barry and Ellis, 2013). Therefore, this paper seeks to answer the following question: can a more varied view of local interests and 'values' mitigate wind turbine siting conflicts?

To answer this question, a mapping of controversy is performed on communication between key stakeholders and the opposition in connection with the mandatory public hearing as part of the planning procedures at the National Test Centre for Large Wind Turbines in Denmark (DTU, 2016) (hereafter, the Test Centre). The mapping of controversy was followed up by an exploration of value proposition from different acceptance dimensions and value perspectives using the Value Framework (den Ouden, 2012).

The paper is structured as follows. Section 2 introduces the methodology namely the discourse analysis used for controversy mapping between central actors and the adapted Value Framework. 
Section 3 presents the case (the Test Centre) and the results from the controversy mapping. Section 4 map the themes of controversy and explores the values of the Test Centre from multiple acceptance dimensions and value perspectives. Section 5 discuss the usefulness of using an integral view on 'value' in connection with wind turbine siting. Section 6 arrives at conclusions on how a more varied view of local interests and 'values' can mitigate wind turbine siting conflicts with some reflections considering policy implications for siting wind turbines.

\section{Methodology}

\subsection{Discourse analysis}

The siting of the Test Centre was a political decision that involved new social relationships between several parties with diverse characteristics and location attachments. Therefore, in order to map the controversy, discourse analysis was applied to hearing statements and letters to the editors of national and local media to identify different ex-ante positions at the Test Centre (Laclau and Mouffe, 2001:105). Laclau and Mouffe (2001:96) describe discourse analysis as: “... an articulatory practice, which constitutes and organizes social relations". This articulatory practice is further defined as “... any practice establishing a relation among elements such that their identity is modified as a result of the articulatory practice. The structured totality resulting from the articulatory practice, we will call discourse"' (Laclau and Mouffe 2001:105).

A discourse analysis involves analysis of all text in relation to a discourse to provide a rich, thick and detailed description. However, to limit the workload analysis was limited to communication between the most central actors (see 2.1.1) in the period from the announcement of the Test Centre siting in Østerild on 30.09.2009 (the first-order observation), until approval of the Test Centre by the National Parliament on 15. J une 2010. This includes 140 responses to the mandatory public hearing of the Environmental Impact Assessment (EIA) on 7J anuary 2010.

\subsubsection{The central actors}


The following people were identified as central actors (authors of texts either in favour, in opposition, undecided, or first-order) and their communication in the form of letters to newspaper editors or responsible authorities was analysed:

- Landowners representing the community in Østerild: Henrik Svanholm ${ }^{1}$ (opponent, 5 texts) and J ochum Kirsebom ${ }^{1}$ (opponent, 3 texts).

- Ministry of the Environment: former minister Troels Lund Poulsen (proponent, 1 text), acting minister Karen Ellemann ${ }^{1}$ (proponent, 1 text), vice director Svend Koefoed-Hansen (first-order text).

- The Danish Society for Nature Conservation: CEO Rene la Cour Shell ${ }^{1}$ (opponent, 3 texts).

- MP's acting as environmental policy spokesmen from 3 parties: Steen Gade ${ }^{1}$ from the Peoples Socialistic Party, SF (has only been interviewed as a proponent), J ohs. Poulsen ${ }^{1}$ from the Social-Liberal Party, B (opponent, 3 texts) and Mette Gjerskov ${ }^{1}$ from the Social Democratic Party, S (has only been interviewed as undecided).

- The Danish Wind Power Industry: CEOJ an Hyldberg' (proponent, 1 text).

The central actors were identified by an Internet search with the terms 'Østerild' and 'wind power'. This gave a list of local landowners, NGO's and civil servants in the Ministry of the Environment. The list was completed by asking these individuals who they believed were central actors. Technical correspondence was not considered, nor were internal ministerial communications as they are considered confidential.

The main purpose of the discourse analysis is to map issues of controversy by the identification of nodal points. A nodal point is a central term articulated by a text and given a particular, momentary meaning (Phillips, 1999).

\subsection{The Value Framework (adapted from den Ouden, 2012)}

\footnotetext{
${ }^{1}$ Has been interviewed to clarify uncertainties concerning the analysed text and for background information.
} 
While discourse analysis can help map a controversy by identifying important themes and how these are assigned meaning by different actors, it does not address the value behind the themes. The Value Framework (den Ouden, 2012), however, offers an approach for describing value propositions that benefit a network of stakeholders using value perspectives from economics, psychology, sociology and ecology. The framework explores 'value' for business innovations across users, organisations, business ecosystems, and society. In Elke den Odens' book 'Tnnovation Design' (2012), she states that we need to create solutions that people love to use: The ultimate solution is therefore the one that provides a pleasurable experience for end-users, with the ability for the organizations involved to do well, sustainably. Only in this way will there be a big enough positive impact at societal level and will real transformation take place' (den Ouden, 2012 p. 5). This statement witnesses that the framework has been developed for services and products with a perceived value for the end user, omitting that the same service or product might have a more complex impact on communities. Thus, neighbouring communities that perceive no pleasurable experience from wind turbines will most likely try to obstruct planned developments.

In order to use the value framework in the context of mapped wind power controversies, it is necessary to redefine the four levels' described in the original version (the four perspectives are not modified), allowing the framework to operate with different controversy dimensions (Fig. 1). Thus, the value levels have been redefined to acceptance dimensions in accordance with Wüstenhagen et al. (2007) as described in Section 2.2.1- 2.2.3.

Wüstenhagen et al. (2007) use three dimensions of acceptance (instead of the four levels of value in the original Value Framework). These dimensions is latest defined by Wolsink (2012) as 1) sociopolitical acceptance related to the support or resistance towards policies that effectively promote the implementation of wind power: 2) community acceptance, concerning decisions about the integration of a wind power scheme at a certain location (see Wolsink, 2007 for examples); and 3) market acceptance, which is about each actor's willingness to invest, including consumer 
willingness to pay for wind-generated power. However, value perspectives from economics, psychology, sociology and ecology are applied as described by den Ouden (2012) and only briefly explained before they are applied to the identified themes of controversy (Figure 2, and Section 3.2).

\subsubsection{Socio-political acceptance dimension}

Acceptance on the most general dimension and indicators demonstrate that public acceptance of wind power is very high in Europe (89\%) (Eurobarometer, 2011). This acceptance is also the case in Denmark (85\%) (Megafon, 2015), where the overall strategic goal is that $49 \%$ of the electricity demand should be covered by wind power in 2020. In addition, the wind power industry represented $4.1 \%$ of the total Danish exports in 2016 (DWIA, 2017) and is therefore considered an industry of national interest. These circumstances have been decisive for the political agreement that led to the establishment of the Test Centre in the northern region of Denmark (see Section 3.1).

\subsubsection{Market acceptance dimension}

In the wider understanding of market acceptance, the focus is on consumers and investors. Several municipalities in Denmark have a $\mathrm{CO}_{2}$-neutral strategy (e.g., The Copenhagen 2025 Climate Plan and Project Zero in Sønderborg, South Denmark), creating a significant demand for wind power. Thus, HoFor, a Copenhagen-based utility, has invested in several wind power developments outside greater Copenhagen with a total capacity of 37.8 MW in 2017.

In Denmark, a mapping of investment models has identified five different approaches and three hybrids, ranging from smaller projects (Usually small <10MW, but can be larger) benefitting local communities to large commercial projects owned by large utility / large private corporation (250 MW - X GW) (Cronin et al., 2017). These investments have ensured that 38\% of the Danish consumption has been covered by wind power by 2016 (Energinet, 2017). In general, the market 
for wind power is well established, and power connections abroad secure that electricity from wind power can be sold in a larger market in periods where the production exceeds domestic consumption (Energinet, 2017).

\subsubsection{Community acceptance dimension}

Community acceptance refers to the specific acceptance of siting decisions and renewable energy projects by local stakeholders, particularly residents and local authorities. Conflicts about wind turbines have their origin at this dimension because local actors are concerned with uncertainties about negative impacts on their life and livelihood. Moreover, the community dimension is equivalent the microsocial level defined by Fournis and Fortin (2017), which can be summarized as a contextualized rationality of complex social mediations expressed through symmetrical and plural processes of local actor engagement and strategies. In the case of Østerild, the community is defined by the neighbours who have expressed their concerns in connection with the public hearing in the period 7J anuary to 5 March 2010.

\section{Data and case}

A holistic single-case design (Yin, 2014 p. 51) was applied to test the hypothesis considering the usability of a value framework to assess the acceptability of a technological change, i.e., the development of the Test Centre.

\subsection{The national test centre for very large wind turbines}

On the evening of 30 September 2009, a letter arrived by taxi to landowners in Østerild. The letter informed the landowners that the Danish government had decided to place a national Test Centre for marine and onshore wind turbines on Østerild plantation. The letter indicated that their properties probably needed to be expropriated. 
The Test Centre is a pilot and demonstration plant for very large wind turbines, and according to a political agreement on 28 May 2010 between the Government and their allies in the Danish Parliament, Østerild plantation was selected to host the Test Centre. The government decided that the Test Centre should be established as a Construction Act due to its importance to the national interest. The establishment of the testing station was specified in the act and allows for seven sitings of wind turbines up to $250 \mathrm{~m}$ in height. During the spring of 2017, the Danish Government decided to expand the Test Centre; in the future, it can host two more wind turbines with heights up to 330 meters. The Østerild area is a primarily state-owned forest area, and the act allows for clear-cutting of up to 550 ha of forest. Some of the forest land will be replaced by wetlands and other nature restoration initiatives. Anker et al. (2012) report that there has been substantial local opposition to the testing station, leading to several complaints, e.g., to the EU Commission by the Danish Nature Conservancy Organisation lodged in August 2010. In addition, the Attorney General viewed the Environmental Impact Assessment (EIA) report and decided that it is fundamentally flawed. However, the Ministry of the Environment, which is responsible for the planning of the project, has complied with the criticism of the attorney general by performing additional EIA, and the Test Centre opened in October 2012.

The Test Centre is owned by the state of Denmark, and the Technical University of Denmark was appointed to manage the establishment and operation of the wind turbine prototype test facility. The wind turbine prototypes are owned by the manufacturer, who rents the test site. The manufacturer also owns the power produced by the wind turbines. For further description of the Test Centre please visit http:// www.vindenergi.dtu.dk/ english/test-centers/ oesterild.

\subsection{Public hearing}

The EIA for the construction of the Test Centre involved public hearings from 7J anuary 2010 to 5 March 2010, resulting in 140 responses. Two of the responses supported the construction; the rest 
were against it. These responses have been analysed, considering the concerns expressed about the impact of the Test Centre. Figure 2 is a thematic mapping of these concerns.

Explanation of thematic concerns expressed by the local community in connection with the Test Centre, referring to Figure 2:

1. Loss of unique landscape and nature: the Test Centre is being placed in a unique landscape characterized by silence and a unique absence of light pollution.

2. Expropriation, compensation and exploitation: fear of economic loss from inadequate compensation for expropriation of property and compensation for loss of value, as well as limits on land cultivation.

3. Inadequate reforestation and restoration of habitat: to avoid turbulence, a large area of forest will be cut down; thus, the concerns focus on a loss of valuable nature that cannot be made up for by compensatory afforestation and habitat restoration.

4. Inappropriate planning process: general discontent with the whole process, in which the local community feels disempowered and trades respect less. Some responses talk about an undemocratic procedure.

5. Disturbance of wild life (e.g., birds, bats and deer): the Test Centre is adjacent to international bird protection areas, and the local community fears that the birds will be disturbed. The same concern exists for deer, which are the largest wild animals in the heavily cultivated Danish countryside. Bats are on the list of protected species in the "Habitats Directive" of the EU.

6. Noise nuisance and impact on health: fear of annoying noise from the wind turbines and concern that low frequency noise may affect the health of both humans and animals.

7. Impact on the environment in general: this is a broad category covering various concerns because of the impact of the wind turbines on the environment, especially during the construction phase and whether mitigating measures are adequate. Additionally, concerns of the washing out of nutrients to the nearby lake were expressed. 
8. Pollution of Groundwater: concerns of the consequences for drinking water because of the expected rise in groundwater level after deforestation.

9. Other: Everything that did not fit into the previous categories.

These thematic concerns will be assigned to different acceptance dimensions and value perspectives in Section 4, allowing a more in-depth analysis of the deeper 'values' driving the concerns.

\section{Mapping themes of controversy}

J udging from the interviews, there was a strong division (with a tendency to be hostile) between the views of opponents and proponents of the Test Centre. The Centre opponents most often referred to the decision process as being flawed (using phrases such as 'scandal', 'undemocratic', 'obscure', and 'arrogant') and the environmental and social impact on the community as devastating (using phrases such as 'demolition of a forest reserve', 'destroying recreational habitats', and 'light pollution'). Proponents, however, addressed the necessity of a closed process ('avoid unnecessary concerns', 'thorough assessment, and 'the best solution') and the national importance of the Test Centre (using phrases such as 'supporting green transition', 'strong position in the world market, and 'creation of strategic know-how'). Thus, opponents and proponents address different subjects except when describing the value of the demolished forest; the preferred phrase among opponents is 'forest reserve', while proponents use' the much less valued 'dune plantation'. In general, the opponents criticized the closed process and that they were not involved until the decision was made by the Ministry of the Environment. Moreover, opponents bemoaned the considerable deforestation in an area where this habitat is rare, and the wind turbines would mean the end of the least noise and light-polluted area in Denmark. Figure 2 shows that the impact on landscape and nature is of highest concern among the opponents. However, this might be a consequence of the demur itself because as soon as the project is considered of national interest, the community only needs to be involved in considering the design of the project. For 
example, most EIA consider bats as they use the EU Habitats Directive as an endangered species. The Danish Society for Nature Conservation as such is not against wind turbines, but it worries that the disregard for the national preservation act of forests will be a slippery slope.

However, proponents put an emphasis on the strategic importance of the Test Centre and do not consider the deforestation of the forest a problem for two reasons: the forest will be replanted elsewhere (1:1.6; 2), and the habitats will be transformed into what is the natural type of the area. Finally, a closed process is not unusual in regard to technological changes of national interest in the Danish democracy. This is not necessarily in contradiction with the Aarhus convention that secures the right of access to documents for citizens and gives citizens the right to complain if they are affected.

\subsection{Exploring value from the Test Centre}

In the following section, the adopted Value Framework is applied to analyse the perceived value from the four predefined perspectives and acceptance dimensions mentioned in Section 2.1.

\subsection{The economic perspective}

Use value is a concept in economics saying that the value of a good or service is related only to its mode of use or to an equivalent value in cash and not to any intrinsic value. No intrinsic value exists for any good or service except its price, which reflects its demand and supply position and

not any inherent quality (Business Dictionary, 2014). This definition of use value is firmly placed within an economic paradigm, namely, in terms of the monetary sacrifice people are willing to make for a product. The emphasis is on the point of exchange, and money is seen as a fundamental index of value (Boztepe, 2013). 
Since neighbours to wind turbines seldom are paid directly from the wind turbine owners (except if they own shares), the proximity to wind turbines has no use value and may be considered as an externality.

Externalities are a loss or gain in the welfare of one party resulting from an activity of another party, without there being any compensation for the losing party (Business Dictionary, 2014). The legal framework for the siting of wind turbines in Denmark obliges wind energy developers to compensate neighbours for loss of property value above 1 per cent (Anker, 2015). In this way, it may be claimed that the negative economic impact of the wind turbines is compensated for. In the case of the National Test Centre, a total of 31 neighbours were granted compensation. One neighbour living $524 \mathrm{~m}$ from the nearest light marking tower was granted a compensation of 1 million DKK. The Valuation Authority emphasized that the recreational value of the property, which had a large influence on the total property value of 2.4 million DKK, was significantly affected. In the case of the National Test Centre, no shares were issued to the community, which otherwise is mandatory for commercial developments (Taksationsmyndigheden, 2010). Moreover, the electricity produced by the wind turbines is owned by the owners of the wind turbines (i.e., the manufacturers of the wind turbine being tested).

Thus, from an economic perspective, the community does not gain value, and compensation can only be seen as neutralizing any loss in property value. Figure 2 appears to show that 26 neighbours have concerns about issues of expropriation and compensation. Many of these address the inconvenience of expropriation regarding access to farming.

\subsection{The psychological perspective}

According to den Ouden (2012, p. 37), the overall value for people is well-being or quality of life. Veenhoven (2000) operates with four qualities of life: 1) liveability of the environment, 2) lifeability of the individual, 3) external utility of life, and 4) inner appreciation of life (Table 1). 
In the political acceptance dimension, an opinion poll (Megafon, 2015) shows that Danes, in general, are in favour of wind power development because wind power is seen as a clean technology with little or no pollution and $\mathrm{CO}_{2}$ emissions, and similar positive opinions have been found in the UK (Bell et al., 2005) and in New Zealand (Energy Efficiency and Conservation Authority, 2012). Two of Veenhoven's quality types can explain this, namely, 'liveability of the environment' (i.e., good living conditions) and 'utility of life' (i.e., reducing climate change from $\mathrm{CO}_{2}$ emissions, caring about the future of the next generation).

However, in regard to the sitings of wind turbines and hence the community dimension, the picture looks quite different, where protests from citizens of the local communities often delay or stall the development. This paradox between general national support and local resistance has been named the 'gap' (Bell et al., 2005).

Figure 2 shows that the main concern the community has regarding the technological change is the negative impact of the Test Centre on nature and the unique landscape and nature values, which can be explained as a perceived decline in the liveability of the environment.

The community acceptance studies from Sweden and the Netherlands show that noise from wind turbines in the range of 35-40 dB will annoy 9 - $20 \%$ of people living close to wind turbines (Pedersen and Waye, 2007; Pedersen et al. 2009).

The Danish legislation on wind turbine noise protects the neighbours in the same area from noise (Table 2). Approximately $20 \%$ of the neighbours are affected when the wind turbines are working at full load. In addition, from J anuary 1, 2012, wind turbines limit values (20 dB behind closed windows) for low frequency noise as a response to concerns regarding low frequency noise (Miljøstyrelsen, 2012). 
In the community acceptance dimension, noise is a concern because it has been argued that noise has an impact on physical health and thus the 'life-ability of the person'. No scientific evidence has hitherto been presented on the harmful effects from wind turbine noise (including low frequency noise), nor has a physical explanation been put forward for the wind turbine syndrome (Harrison, 2015). However, a recent review of studies examining the symptoms related to modern technology (including wind turbines) found that health symptoms were more commonly reported among participants who were more anxious, worried, concerned, or annoyed by a source they perceived to be a health risk. The authors suggested that annoyance may promote changes in physiology, behaviour, self-monitoring or enhanced recall bias (Rubin et al., 2014).

Negative publicity on the health effects from wind turbines may also affect life quality. An Australian case study describes a dramatic increase in expressed concerns about health and other issues published in local news media immediately following a public meeting organized and addressed by dedicated opponents of wind farms from outside the area (Chapman et al., 2014). Thus, it is probably not the wind turbines themselves but rather a confirmation bias, which is a cognitive phenomenon where people search for, interpret, and prioritize information in ways that confirm their beliefs (Klayman, 1995). It appears that the impact from wind turbine noise on quality of life must be understood from a psychological perspective, focussing on mental functions (signal modulation and processing in the brain) rather than a physician perspective focus on the functioning of the body.

\subsection{The sociological perspective}

The following definition for sociological value is used here: a larger concept, which includes social capital as well as the subjective aspects of the citizens' well-being such as their ability to participate in making decisions that affect them (IMP, 2017). 
The Test Centre is considered a national interest as it will contribute to meeting the government's declared goal of 49\% of Denmark's electricity consumption being supplied by wind power by 2020 (DTU, 2012). Hence, the Test Centre can be seen as having societal value and a political acceptance of the need to develop efficient wind turbines. The Test Centre is an important asset to this end.

In the community acceptance dimension, the perceived lack of participation in community wind turbine planning seems to generate lack of recognition witnessed by the concerns for the fairness in the process ranking fourth (Fig. 2). Since it is in relationships that things take on value, this may in part explain why wind power projects have been confronted with very different responses locally (Huber et al., 2012). According to Wolsink (2012), questions on distributional justice are often the source of conflicts because the community perceives wind turbines as a burden, while someone from the 'outside' harvests the benefit, i.e., remote wind turbine owners. Surely lack of empowerment and collaborative decision making will raise questions on trust-related issues because distribution of cost and benefits becomes non-transparent. However, projects that both involve the community and generate benefits locally have been reported to create less opposition (Bak, 2012).

In the case of the Test Centre, it is difficult to identify any social value with a positive impact in the social acceptance dimension since the centre only provides a few jobs in the community, and the electricity produced is owned by the manufacturers testing the wind turbines. The fact that the Test Centre supports Denmark's leading position in the wind turbine market can hardly be seen as contributing to the community well-being. Furthermore, the public hearing response shows that the planning process is not perceived as being fair (Fig. 2). Clearly, what has been named an 'undemocratic' process has contributed to the conflicts during the development of the Test Centre. Finally, the locals feel that the government has bullied the project through, for example, referring to some hard-hearted statements about the local community by the Minister of the Environment at the time (Borch, 2010). 


\subsection{The ecological perspective}

Nature and landscapes are important for human society and provide great ecological, socio-cultural and economic value (de Groot, 2006). Therefore, the clearcutting of 266 ha plantation of the forest to make room for the Test Centre must be considered a loss in nature values. To compensate, 419 ha of forest will be established over a period of several years, 100 ha of the forest on current agricultural land in Østerild. Generally, the Nature Agency has gone to great lengths to restore the nature to open and moist habitats as it was before it was planted with Sitka spruce to prevent sand drift a century ago (1889-1940). The restoration of the indigenous habitat, together with the Test Centre potential to support the displacement of fossil-based energy production, support the argument that the Test Centre has a positive value from an overall ecological perspective (the political acceptance). Against this argument, the Danish Society for Nature Conservation (whose primary objective is conservation and protection of the Danish forests) sees the deforestation as a serious departure from the principles of the Forestry Act (Retsinformation, 2017).

In the community acceptance dimension, restoration of the indigenous habitat is not perceived as a gain since this type of habitat is abundant in the area (Fig 2.). In contrast, as one interviewed local citizen stated, "We have very little forest in these parts". The Nature Agency itself describes the Østerild plantation as 'characterized by its great variation but also by the numerous services to the forest visitors' (Naturstyrelsen, 2012).

Finally, concerns were expressed concerning how the wind turbines might affect the neighbouring 'Natura 2000' areas and its bird population. Bats were also mentioned due to their status as an endangered species. Denmark is heavily cultivated, and therefore, many of the local citizens value the presence of deer in their natural habitat and fear that the Test Centre will threaten this (Fig 2).

\section{Discussion}


In a recent debate, the director of the Danish Wind Industry and the president of the Association of Wind Turbine Owners claimed that National Association of Neighbours to Giant Land Wind Turbines travel with myths and misinformation on the question regarding noise from wind turbines' (Bjerre \& Hyldeberg, 2013). However, the National Association of Neighbours of Giant Windmills has responded that stress needs to be a part of the investigation of noise from wind turbines and claim that the wind industry is misinforming the public concerning the negative aspects of wind turbines. This is a fine example of how actors strategically advance their interests through construction and dissemination of narratives that promote their interests and values.

Discourse theory is based on the premise that meaning is socially constructed and that actors have a different capacity to influence narratives in the public. These activist groups and political constituencies assert new forms of knowing that challenge dominant scientific explanations and calculations. In his book 'The Risk Society', Bech (1992) witnessed how such alternatives to a dominant narrative are sought out to challenge the monopoly of the sciences on rationality, which in turn led to Gibbion's notion on science's new contract with society (Gibbons, 1999). In the Australian discourse on energy policy, Curran (2012) has demonstrated how narratives have cast doubt on and created reasonable uncertainty about the capacity of a country to continue meeting its socio-economic obligations of renewable energy. Indeed, wind power projects as demonstrated in this value mapping, are a subject of disagreement and controversy.

By combining Wüstenhagen et al.'s (2007) triangle of social acceptance with den Ouden's (2012) Value Framework, it is possible to map controversies to address the duality of 'technological' and 'social' explanations of values (J ovilet and Heskinen, 2012), which will be discussed next.

From an economic perspective, the analysis explains how society can gain economic value as the wind turbines are profitable exports for Denmark (DWIA, 2017) and generally have the potential of supporting rural development (OECD, 2012). Although the community does not suffer 
economically (they are compensated for any value loss their property may suffer from the proximity to the wind turbines), the energy produced at the Test Centre does not benefit the community.

Value in the economic perspective is tangible, and hence, the community's economic advantage from the wind turbines can be negotiated. Thus, OECD (2012) has listed a number of economic offerings to communities from renewable energy: new revenue sources by increasing the tax base for improving service provision in rural communities; affordable energy that triggers economic development from the availability of reliable, cheap energy; and new job and business opportunities, created when the renewable energy activity is embedded in the local economy.

An example of how wind turbines can benefit local economy is the wind turbines at the two Danish west coast harbours: Hvide Sande and Hanstholm. They are owned by a significant number of locals and a trust investing in local infrastructure benefiting economic development (Bak, 2013).

From a psychological perspective, it can be argued that society in general obtains value from the fact that wind power relieves the concerns about fossil fuels, pollution and climate change, and hence, the technology is politically acceptable. It is more complex in the community acceptance dimension, in which the wind turbines create anxiety among some members of the community, both concerning outer qualities (loss of nature and unique landscape) and inner qualities (health concerns). Since anxiety concerning the inner qualities are individual, opaque and not necessarily rational, they need to be handled appropriately; otherwise, it might lead to distrust and conflict that spread to the rest of the community (Ogilvie and Rootes, 2015, Waren and McFayden, 2010). As Ellis and Ferraro (2016) express, "a profusion of local conflicts around wind energy project can begin to change nation discourses on the need to develop wind energy and, potentially, erode wider political support and a failure to achieve renewable energy targets. The change of discourse is even more pronounced when social media are used strategically by opponents (Reusswig et al., 2016, 
Borch et al., forthcoming). Therefore, it is in the interest of the wind power industry to recognize and identify the individual sources of anxiety to engage in a constructive dialogue with the community and to improve technological acceptability accordingly (Fournis and Fortin, 2017). The dissatisfaction with the process (Fig. 2) might explain the gap between the societal values and the perceived community value. Thus, the planning process seems to accumulate resistance because the public space offered to citizens is a technical-regulative 'closed space' disempowering the local community (Clausen and Rudolph, 2018; Gaventa 2006).

The sociological perspective describes how the development of efficient wind power technology is politically acceptable in general because wind power displaces fossil-based energy production and hence adds to the common good of non-polluting energy technologies. The market acceptance is increased from innovations coming out of the Test Centre as well as the gained value from internationally recognized research.

The community gains no social value from the proximity to the Test Centre. Moreover, the community has regarded the rhetoric from the authorities as intimidating. It is a serious challenge that the planning process is perceived inappropriate (Fig. 2). The main cause of this mistrust in planning originates in the relatively closed process used in the preparatory phases of developing the Test Centre where the community was only informed of the plans when it was already a fait accompli. A more open process where the community is involved is no guarantee of success, and it is more time-demanding. However, it is to be recommended as it may lead to mitigation of general protests, blocking or delaying projects and increasing future confidence, acceptance and support (Sørensen et al, 2002). Therefore, it is necessary to focus on empowerment and recognition, where recognition is a heuristic that leads away from conflict into a broader understanding of the complexity of a disputed subject, not to reach consensus but to recognize the point of view of other parties (Borch and Merida, 2013). Bush and Folger (2004: 24) claim that it is now possible and 
necessary to go still further and to achieve a full integration of individual freedom and social conscience, in a relational social order enacted through new forms of social processes and institutions'. In line with this approach, Daniels et al. (2012) have suggested that the Unifying Negotiation Framework is an integrative model of policy negotiation that conceptualizes decision processes as discourses in several levels, supporting ex ante evaluation and design. These levels are much in line with the acceptance dimensions suggested by Wüstenhagen et al. (2007).

The environmental perspective reveals some interesting paradoxes. First, wind turbines are considered a green technology, but to the community, the local impact on valued habitats is of greater importance, witnessed by the substantial opposition to the change or loss of nature and landscape values (Fig. 2). Second, along the same lines as the first paradox, although it is concerned about the impact of the Test Centre, the Danish Society for Nature Conservation supports wind power featuring green energy. However, it should not be at the expense of what they regard as unique nature values. Third, the suggested reestablishment of the natural heathland might seem valuable for an outsider but not to the locals who value the forest, which is a rarity in these parts of Denmark. The fact that reforestation was increased from 1:1 to 1:1.2 did not seem to soothe the community concerns. It gave rise to mistrust because it was not suggested from the very beginning of the negotiations.

\section{Conclusions and policy implications}

The paper set out to test the hypothesis that analysis combining the 'triangle of social acceptance' (Wüstenhagen et al., 2007) and the Value Framework (den Ouden, 2012) can give a more varied picture of perceived values concerning technological change in communities. We ask the following question: Can a more varied view of community interests and 'value' mitigate conflicts over wind turbine sitings? 
This analytical approach has systematically demonstrated how political and market acceptance are improved due to the value gained from the Test Centre. However, community acceptance is seriously challenged as the local residents perceive no value from living next to the Test Centre.

Thus, the answer to the question is that a more varied view is necessary to understand why conflicts over wind turbines exist, but it does not prevent escalating conflicts over controversies unless the values and interests in the community dimension are integrated into the planning process appropriately.

Value mapping in the three dimensions of socio-political, market and community acceptance gives rise to several policy implications:

First, the closed process leaves the community in a situation of disempowerment in which they do not recognize the value of the societal dimension. Thus, a more open process in which the community is empowered would not only allow for a stronger recognition of societal values but also inspire win-win solutions in which the renewables would provide several community benefits.

Second, trust in the authorities is low because of the closed process and because community values are neglected until very late in the process, at a point at which the scope of changes to the project design is severely limited. If the process had been more open, capacity-building and community empowerment could have been achieved, for example, if the community had been consulted concerning the ideas for landscape restoration.

Third, negative media coverage from the project will inevitably have negative consequences for future wind power developments. This is even more crucial with the appearance of social media where wind turbine opponents communicate concerns easily. Therefore it is recommended to establish a strong proactive community strategy that includes the social media before the project is made public. 
In general, the limitation in public access to central documents in ministries and agencies is problematic. It is not clear why the ministry preferred a closed process over a more open one when planning for the Test Centre. However, in an interview, the Minister of the Environment indicated that in hindsight she would prefer a more open process for future wind power projects.

In the case of the Test Centre, a more open process alone probably would not have appeased the community concerns (preventing the escalation of the conflict). However, a thorough analysis of the value perspectives using the suggested analytical framework can benefited the negotiations of siting wind turbines in three ways:

- A proper ex-ante understanding of the significant community concern may lead to different conclusions and a more community-oriented, sustainable policy direction.

- A more transparent process in which the community is empowered (i.e., able to satisfy needs) can lead to trust generation and a stronger recognition of the significant societal values of the Test Centre.

- Since wind power has the potential to generate economic value, it appears to represent a golden opportunity for linking renewable energy to rural development.

\section{Acknowledgements}

I would like to express my gratefulness to Dr J ens Emborg, Copenhagen University who provided valuable comments about the manuscript and to DTU for sponsoring my Masters in mediation, which was an invaluable inspiration to this work.

\section{References}

Anker, H.T., 2016. Notat om kommunal planlægning for vindmøller, IFRO Udredning 2016/ 26. Anker, H. T., Jørgensen, M. L. 2015. Mapping of the legal framework for siting of wind turbines Denmark. IFRO Report; No. 239. 
Anker, H.T., Olsen, B.E., Rønne, A. 2012. New government, new rules. IUCN Academy of Environmental Law e-J ournal 1: 79-85.

Bak, K.B. 2012. Wind energy as a lever for local development in peripheral regions. http:// www.folkecenter.net/ mediafiles/ folkecenter/ pdf/Wind-Energy-as-a-Lever-for-LocalDevelopment-in-Peripheral-Regions.pdf (accessed 13.12.2017).

Barry, J ., Ellis, G., 2010. Beyond consensus? Agonism, republicanism and a low carbon future. In: Devine-Wright, P. (Ed.), Renewable Energy and the Public: From NIMBY to Participation. Earcthscan, London, pp. 29-42.

Batel, S., Devine-Wright, P., Wold, L., Egeland, H., J acobsen, G., Aas, O., 2015. The role of deessentialisation within siting conflicts: An interdisciplinary approach. J ournal of Environmental Psychology, 44, 149- 159.

Beck U., 1992. Risk society: towards a new modernity. London: Sage Publications. ISBN: 9780803983465.

Bell, D., Gray, T., Haggett, C., 2005. The 'social gap' in wind farm siting decisions: Explanations and policy responses. Environmental Politics, 144, 460- 477.

Bergek, A., 2010. Levelling the playing field? The influence of national wind power planning instruments on conflicts of interests in a Swedish county. Energy Policy, 385, 2357- 2369.

Bjerre, A., Hylleberg, J ., 2013. Stop fejlagtig debat om vindmøllestøj. Altinget, Energi og Miljø 13.

Borch, K., 2010 Stormen on Vindmøllerne ved Østerild. Master thesis. http:// orbit.dtu.dk/ files/ 126131632/Konfliktm_gling_speciale_krbo_2_.pdf (accessed 15.12.2017)

Borch, K., Munk, A.K. Andersen V. (forthcoming). Tracing how wind turbine opponents communicate concerns through social media.

Borch, K., Merida, F., 2013. Dialogue in foresight: Consensus, conflict and negotiation. In: Borch, Dingli, J ørgensen (Eds.) Participation and Interaction in Foresight: Dialogue, Dissemination and Visions, 97- 117. 
Boztepe, S., 2013. State-of-the-Art Review User Value: Competing Theories and Models. https:// doi.org/ 10.1.1.364.1876.

Bush, A.B.B, Folger, J .P., 2004. The Promise of Mediation. Wiley. ISBN: 978-0-787-97483-1. Business dictionary http:/ / www.businessdictionary.com/ definition/ use-value.html. (accessed 01.05.2017).

Chapman, S., J oshi, K., Fry, L., 2014. Fomenting sickness: Nocebo priming of residents about expected wind turbine health harms. Frontiers in Public Health, 2, 279.

Clausen, L. \&Rudolph, D. 2018. (Dis)embedding the wind - on people-climate reconciliation in Danish wind power planning. The J ournal of Transdisciplinary Environmental Studies, special issue on contemporary Perspectives on People-Nature Reconciliation. Accepted.

CONCITO, 2012. Lokal accept og udvikling af vindmølleprojekter Opsamling på Wind2050projektet. http:// www.wind2050.dk (accessed 01.06.2018).

Cronin, T., Kirkegaard, J .K., Borch, K, 2017. Mapping of wind turbine ownership models in DK. Wind Energy Science Conference - WESP, Risø, Denmark.

Curran, G. 2012. Contested Energy Futures: Shaping renewable energy narratives in Australia. Global Environmental Change-Human and Policy Dimensions 22 1, 236-244.

Daniels, S. E., Walker, G. B., Emborg, J ., 2012. The unifying negotiation framework: A model of policy discourse. Conflict Resolution Quarterly, 301, 3- 31.

de Groot, R., 2006. Function-analysis and valuation as a tool to assess land use conflicts. In Planning For Sustainable, Multi-Functional Landscapes. Landscape and Urban Planning 75, 175-186.

den Ouden, E., 2012. Innovation Design. Springer London.

Devine-Wright P., 2011. Public engagement with large-scale renewable energy technologies: breaking the cycle of NIMBYism. Wiley Interdisciplinary Reviews: Climate Change 21:19-26.

Devine-Wright, P., Howes, Y. 2010. Disruption to place attachment and the protection of restorative environments: A wind energy case study. J ournal of Environmental Psychology, 30(3), 271- 280. 
DTU, 2017. Welcome to Østerild. http:/ / www.vindenergi.dtu.dk/ english/ / media/ Institutter/Vindenergi/Oesterild/ Oesterild-Testcenter-UK-opslag.ashx (accessed 26.02.2018)

DWIA, 2017. Industry Statistics. http:// www.windpower.org/ en/ knowledge/ statistics.html (accessed 16.12.2017).

Eurobarometer, 2011. Special Eurobarometer 364 / Wave 75.1. Public Awareness and Acceptance of $\mathrm{CO}_{2}$ Capture and Storage. Directorate General for Energy.

Ellis, G., Ferraro, G., 2016. The social acceptance of wind energy; EUR 28182 EN, doi $10.2789 / 696070$

Ellis, G., Barry, J ., Robinson, C., 2007. Many ways to say 'no', different ways to say 'yes'. J ournal of Environmental Planning \&Management, 50: 517-551.

Eltham DC, Harrison GP, Allen SJ . 2008. Change in public attitudes towards a Cornish wind farm: implications for planning. Energy Policy 361, 23-33.

Energinet, 2017: Annual report for 2016. https:// energinet.dk/ Ompublikationer/ Publikationer/ Aarsrapport-2016 (accessed 10.12.17).

Energy Efficiency and Conservation Authority, 2012 Public perceptions of renewable energy surveys. http:// www.eeca.govt.nz/ eecaprogrammes-and-funding/ programmes/ energy-supplyrenewableenergy-programme/renewable-energy. (accessed 01.10.2016).

Firestone, J ., Kempton, W., 2007. Public opinion about large offshore wind power: Underlying factors. Energy Policy, 35(3), 1584- 1598.

Fournis, Y., Fortin, M.-J ., 2017. From social 'acceptance' to social 'acceptability' of wind energy projects: towards a territorial perspective. J ournal of Environmental Planning and Management, 601, 1- 21.

Gaventa, J . (2006). Finding the spaces for change: A power analysis. Ids Bulletin-Institute of Development Studies, 37(6), 23.

Gibbons, M., 1999. Science new contract with society. Nature, Vol 402 Supp: c81-c84. 
Harrison, R. V., 2015. On the biological plausibility of Wind Turbine Syndrome. International J ournal of Environmental Health Research, 255, 463-468.

Huber, S., Horbaty, R., Ellis, G., 2012. Social Acceptance of Wind Power Projects: Learning from Trans-National Experience. In Szarka, J ., Cowell, R., Ellis, G. Strachan, P.A. and Warren C. (Eds.), Learning from Wind Power. Palgra Macmillian, Hampshire, UK, p. 215-234.

Hørringsportalen, 2010. Hørringsnotat om VVM redegørelse: Nationalt testcenter for vindmøller ved Østerild. https:// prodstoragehoeringspo.blob.core.windows.net/ 801e84bf-f604-4297-94bafcdba25d5859/H\%C3\%B8ringsnotat\%20om\%20VVM\%20redeg\%C3\%B8relse.pdf (accessed 26.02.2018).

IMPact management project: http:/ / www.impactmanagementproject.com/ glossary/ s/ (accessed 13.12.17).

J ohansen, K., Emborg, J . 2018. Wind farm acceptance for sale? Evidence from the Danish wind farm co-ownership scheme. Energy Policy, 117, 413- 422.

J olivet, E., Heiskanen, E., 2010. Blowing against the wind - An exploratory application of actor network theory to the analysis of local controversies and participation processes in wind energy. Energy Policy 38, 6746-6754.

J ørgensen, M.L. 2018. Distributive fairness and wind turbines: the role of com-pensation schemes, (in progress).

Klayman, J ., 1995. Varieties of confirmation bias. Psychology of Learning and Motivation, 32, 385418.

Laclau, E., Mouffe, C., 2001. Hegemony and socialist strategy - Towards a Radical Democratic Politics, Verso.

LadenburgJ , Möller B., 2011. Attitude and acceptance of offshore wind farms: The influence of travel time and wind farm attributes. Renewable and Sustainable Energy Reviews 159, 42234235.

Lilley, M. B., Firestone, J ., Kempton, W., 2010. The Effect of wind power installations on coastal tourism. Energies, 3(1), 1-22. 
Megafon, 2015. http:/ / www.dkvind.dk/ fakta/ M6.pdf (accessed 12.12.2017).

Miljøstyrelsen, 2012. (The Danish Environmental Protection Agency)

http:// eng.mst.dk/ media/ mst/ 66206/ engelsk_ vindmoellebekendtgoerelse.pdf (accessed 16.12.2017)

Natursyrelsen, 2012. Østeril klitplantage.

http:// naturstyrelsen.dk/ naturoplevelser/naturguider/ oesterild-klitplantage/ (accessed 26.02.2018)

OECD, 2012 Linking Renewable Energy to Rural Development. ISBN 9789264180420

Ogilvie, M., Rootes, C., 2015. The impact of local campaigns against wind energy developments. Environmental Politics, 246, 874- 893.

Retsinformation, 2017. https:// www.retsinformation.dk/ Forms/ R0710.aspx?id=186419 (accessed 16.12.2017).

Pedersen, E., Waye, K.P., 2007. Wind turbine noise, annoyance and self-reported health and wellbeing in different living environments. Occupational and Environmental Medicine, 64, 480486.

Pedersen, E., van den Berg, G. P., Bakker, R., Bouma, J ., 2009. Response to noise from modern wind farms in the Netherlands. J ournal of the Acoustical. Society of America, 126, 634-643.

Phillips, l., 2010. Diskursanalyse, In: Brinkmann \& Tankaard (Eds,) Kvalitative metoder, Hans Reitzels forlag, København.

Reusswig, F., Braun, F., Heger, I., Ludewig, T., Eichenauer, E., Lass, W. 2016. Against the wind: Local opposition to the German Energiewende. Utilities Policy, 41, 214- 227.

Rubin, G. J., Burns, M., Wessely, S., 2014. Possible psychological mechanisms for 'wind turbine syndrome'. On the windmills of your mind. Noise and Health, 1669, 116- 122.

Sørensen, H. C., Hansen, L. K., Hammarlund, K., Larsen, J. H., 2002. Experience with and strategies for public involvement in offshore wind projects. International J ournal of Environment and Sustainable Development, 14, 327- 336. 
Taksationsmyndigheden (2010) (Valuation Authority)

http:/ / taksationsmyndigheden.dk/ DA/Afgoerelser/ Nordjylland/Thisted-

Kommune/ Sider/Testcenter-Oesterild.aspx (accessed 15.09.2016).

Van der Horst, D., 2007. NIMBY or not? Energy Policy, 35, pp. 2705- 2714.

Veenhoven, R., 2000. The four qualities of life. J ournal of Happiness Studies 11: 1-39.

Warren C.R., McFadyen M., 2010. Does community ownership affect public attitudes to wind energy? A case study from south-west Scotland. Land Use Policy 272, 204-213.

Wolsink, M., 2012. Wind Power: Basic challenge concerning social acceptance. Meyers, R.A. Ed. Encyclopaedia of Sustainability Science and Technology: Springer. Volume 17, 12218-12254.

Wolsink, M., 2007. Wind power implementation: the nature of public attitudes: equity and fairness instead of ` backyard motives’. Renewable and Sustainable Energy Reviews 116, 1188-1207.

Wüstenhagen, R., Wolsink, M., Buerer, M. J ., 2007. Social acceptance of renewable energy innovation: An introduction to the concept. Energy Policy, 355, 2683- 2691.

Yin, R. K., 2003. Case study research - Design and methods. 3rd ed. s.l.: Applied social research methods series. 
Tables and Figures

\begin{tabular}{|c|c|c|}
\hline & Outer qualities & Inner qualities \\
\hline $\begin{array}{c}\text { Life } \\
\text { Chances }\end{array}$ & $\begin{array}{c}\text { Liveability of the } \\
\text { environment }\end{array}$ & Life-ability of the person \\
\hline $\begin{array}{c}\text { Life } \\
\text { Results }\end{array}$ & Utility of life & Appreciation of life \\
\hline
\end{tabular}

Table 1. Four qualities of life (Veenhoven, 2000).

\begin{tabular}{|c|c|c|}
\hline Wind Speed & $8 \mathrm{~m} / \mathrm{s}$ & $6 \mathrm{~m} / \mathrm{s}$ \\
\hline Residential areas & $\mathbf{3 9} \mathbf{~ d B}$ & $\mathbf{3 7} \mathbf{d B}$ \\
\hline Open land & $\mathbf{4 4 ~ d B}$ & $\mathbf{4 2} \mathbf{~ d B}$ \\
\hline
\end{tabular}

Table 2. Maximum legal exposure level of wind turbine noise calculated as the shortest distance between residential buildings to the nearest wind turbine (Miljøstyrelsen, 2012).

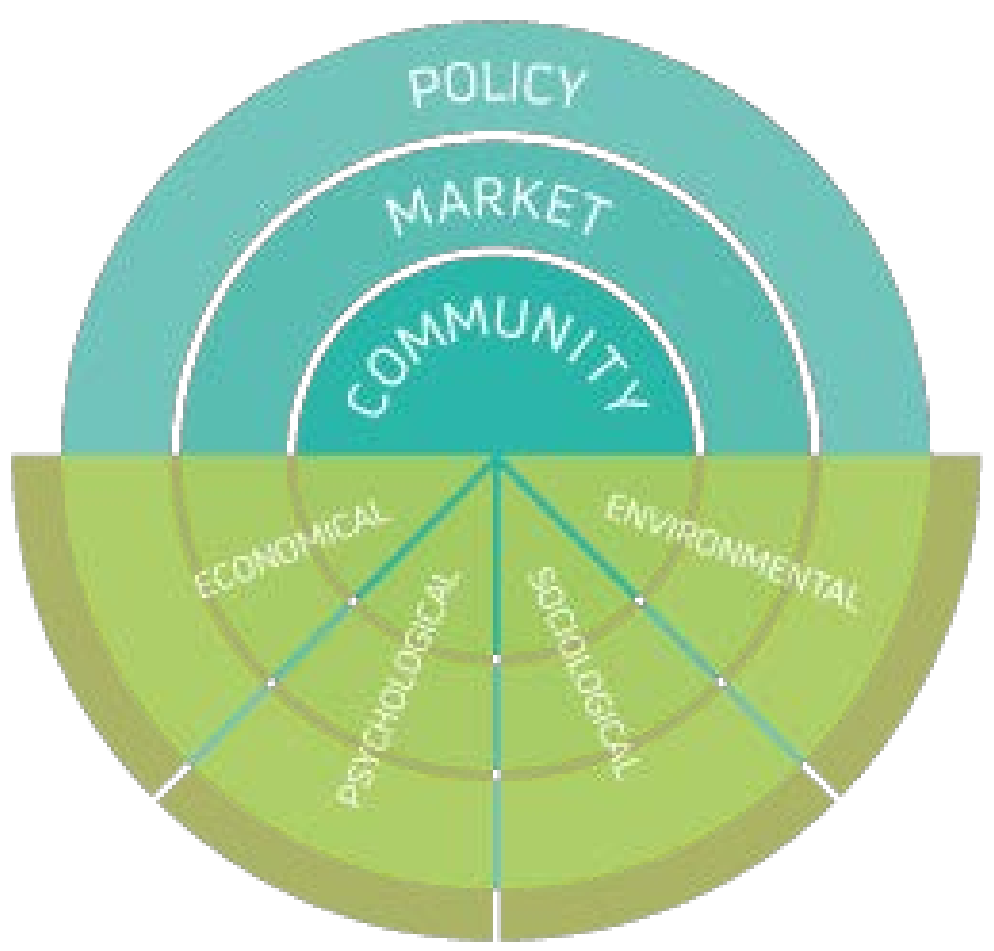

Figure 1. The Value Framework modified from den Ouden (2012, p. 76) 


\section{NUMBER OF OCCURRENCES}

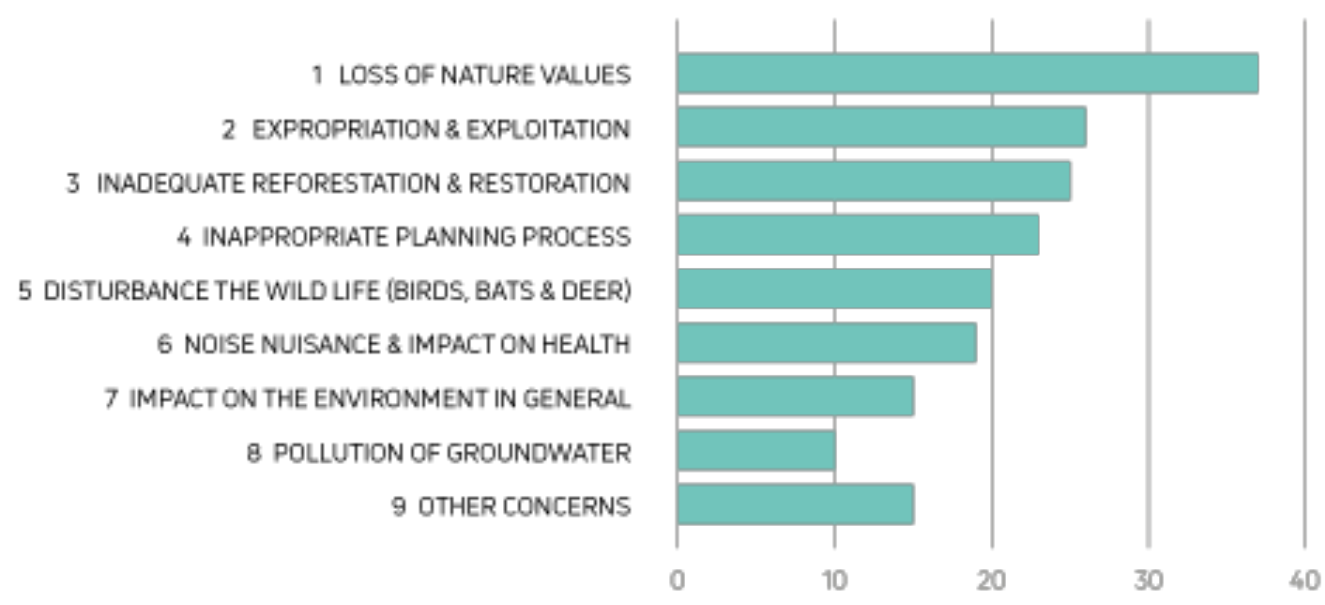

Figure 2. Occurrence of thematic concerns in 140 answers to the public hearing considering the construction act and EIA of the Test Centre (Hørringsportalen, 2010). 